\title{
Communicating Environmental CSR towards Consumers: The Impact of Message Content, Message Style and Praise Tactics
}

\author{
Julia Christis and Yijing Wang *(1) \\ Department of Media and Communication, Erasmus School of History, Culture and Communication (ESHCC), \\ Erasmus University Rotterdam, 3062PA Rotterdam, The Netherlands; julia.christis@t-online.de \\ * Correspondence: y.wang@eshcc.eur.nl
}

\begin{abstract}
While engaging in corporate social responsibility (CSR) has gradually become mainstream in the business context, the investigation of CSR communication and its effectiveness remains limited. This study examines how environmental CSR communication affects consumer perception and behavior through an experiment design. We distinguish three CSR communication factors-message content (climate responsibility vs. sustainable use of natural resources), message style (greenhushing vs. uniform vs. greenwashing) and praise tactics (consumer praise vs. company praise)—and assess their impacts on consumer trust, purchase intention and consumer advocacy, respectively. We also investigate the moderating role of attributed intrinsic and extrinsic corporate motives on engaging in environmental CSR. An online experiment $(\mathrm{N}=304)$ revealed that a uniform message style outperforms the other two styles, whereas greenwashing is found to be least effective. In addition, attributed intrinsic corporate motives moderate the impacts of environmental CSR communication on consumer trust, purchase intention and consumer advocacy, respectively. No moderation effect was found for attributed extrinsic corporate motives. The findings provide important implications for effective environmental CSR communication with respect to specific message styles and attributed corporate motives.
\end{abstract}

Citation: Christis, J.; Wang, Y.

Communicating Environmental CSR towards Consumers: The Impact of Message Content, Message Style and Praise Tactics. Sustainability 2021, 13, 3981. https://doi.org/10.3390/ su13073981

Academic Editor: Andrea Pérez

Received: 4 March 2021

Accepted: 30 March 2021

Published: 2 April 2021

Publisher's Note: MDPI stays neutral with regard to jurisdictional claims in published maps and institutional affiliations.

Copyright: (c) 2021 by the authors. Licensee MDPI, Basel, Switzerland. This article is an open access article distributed under the terms and conditions of the Creative Commons Attribution (CC BY) license (https:// creativecommons.org/licenses/by/ $4.0 /)$.

Keywords: CSR communication; corporate motives; consumer trust; purchase intention; consumer advocacy

\section{Introduction}

The last decade has been marked by increased standoffs between corporations, the public and the governmental sector when it comes to whether and how to combat climate change. Climate change entails a direct or indirect human-induced change in climate that impacts the constellation of the global atmosphere [1]. Factors such as emissions of greenhouse gases and plastic pollution impact the climate to the extent that the system is in danger of becoming irreversibly out of balance, causing sea-level rises, increasing temperatures, ocean acidification, forest degradation, biodiversity loss and desertification [1]. How pressing the issue of climate change really is has emerged within global public consciousness over the last several years, with scientists directing attention to extreme weather events such as the annually increasing wildfires in California [2], or the global disappearing of glaciers [3]. A recent climate catastrophe, a massive outbreak of wildfires in Australia at the end of 2019, during which more than 4.9 hectares of forest were destroyed and 800 million animals were affected, traumatized the public further [4].

Given the global context, businesses' commitment to preserving the planet is demanded by more and more stakeholders across the globe [5]. The resource-based theory emphasizes that providing value to stakeholders can create a competitive advantage for businesses [6]. It implies that businesses need to proactively take the interests of multiple stakeholders into account $[7,8]$. As a consequence, many companies have voluntarily engaged in socially and environmentally responsible behaviors. These practices are described by scholars through a container concept: corporate social responsibility (CSR) [9]. 
CSR continued to garner business attention in the last few decades because of increased pressure from climate organizations [10], stakeholder demands enhanced by communication technologies [11] and the possible long-term profitability of engaging in CSR for businesses [12]. Previous studies revealed that successful environmental CSR can not only benefit the planet but also positively affect consumer perception at a large scale [13].

While a few researchers have examined the impact of CSR communication on consumers [14,15], only a subset of scholars have moved beyond consumer perception to consider how consumers can be incited to commit to their social responsibility [16]. Consumer social responsibility (CnSR) entails consumers' awareness and socially responsible behavior in terms of consumption habits [16]. To date, CnSR is only studied as a unidimensional concept, referring to consumers' purchase intention [17]. Therefore, an important question to consider is whether and how CSR communication may result in CnSR beyond purchase intention.

In addition, Schmeltz [18] claims that the rhetorical and discursive challenges of CSR communication have not been well addressed in the literature. Knowledge on different message styles, such as greenwashing (doing less than the corporate states) or greenhushing (doing more than the corporate states), and how they affect the perceptions among consumers is scarce [14]. Similarly, Kouchaki and Jami [19] argue that the tactics that can be used in CSR messages to psychologically influence consumers still need to be examined. Further, there is a lack of literature on how, in light of pressing climate change, corporations can adapt their CSR communication to prompt consumers to commit to their CnSR [16,20].

To fill the gaps in the literature, this study examines how environmental CSR communication affects consumer perception and behavior through an experiment design. We distinguish three CSR communication factors-message content (climate responsibility vs. sustainable use of natural resources), message style (greenhushing vs. uniform vs. greenwashing) and praise tactics (consumer praise vs. company praise) -and assess their impacts on consumer trust, purchase intention and consumer advocacy, respectively. We also investigate the moderating role of attributed intrinsic and extrinsic corporate motives on engaging in environmental CSR. The findings of this research can provide important implications for businesses with respect to effective communication of their environmental CSR activities and to motivating consumers to commit to their social responsibility.

The remainder of the paper unfolds as follows. In Section 2, we relate the paper to prior studies and develop hypotheses. Section 3 describes the empirical methodology and data. In Section 4, we present the research findings. Section 5 discusses the theoretical and managerial implications. Section 6 concludes the paper.

\section{Theoretical Framework and Hypothesis Development}

\subsection{Environmental CSR and Sustainability}

Khojastehpour and Johns [21] propose the term "environmental corporate social responsibility" and divide it into two aspects: a company's climate responsibility and its sustainable use of natural resources. Climate responsibility entails a company's awareness of its role in the process of climate mitigation [21]. It indicates to what extent a company admits that it needs to contribute to the societal process of tackling climate issues and how the company handles stakeholder demands concerning this issue. On the other hand, sustainable use of natural resources refers to what a company's concrete actions are in responsibly using the planet's resources [21]. It focuses on how companies use their expertise and (innovative) capital to contribute to preserving local and international ecosystems for future generations.

The concept of environmental CSR is inherently linked to sustainability. In 1987, the World Commission on Environment and Development first used the term "sustainable development" in relation to businesses when it released an annual report stating that it is possible for a business to meet its production needs "without compromising the ability of future generations to meet their own needs" [22]. Ever since, both academia and the private sector have been guided by this statement to form definitions of sustainability. For most 
scholars, sustainable business practices go beyond protecting environmental stakes. In the broadest sense, sustainability entails economic, social and environmental integrity [23]. Concepts like social and environmental inclusiveness, connectivity, equity, prudence and security are also directly related to sustainability [24]. In their review of previous corporate sustainability literature, Amini and Bienstock [25] propose a sustainability model in which one of the dimensions frames social and ecological factors as being equally relevant to a business decision as economic factors.

Many scholars, however, differentiate the ecological and social aspects, and focus on environmental sustainability, giving the concept of meeting business needs without depleting natural resources a more urgent position in the debate. According to Shrivastava [26], ecological sustainability entails the full management of a company's natural environment, ecologically sustainable competitive strategies, technology for benefitting nature, and reducing the impact of populations on ecosystems. Morelli [27], who sees ecological sustainability as the basis of the three dimensions of sustainability (environmental, economic, social) because it provides the fundamental ground for and is not dependent on the other two, defines ecological sustainability as

"a condition of balance, resilience, and interconnectedness that allows human society to satisfy its needs while neither exceeding the capacity of its supporting ecosystems to continue to regenerate the services necessary to meet those needs nor by our actions diminishing biological diversity" (p. 5).

Following this definition, environmental CSR can be perceived as the instrument by which or all the actions taken to reduce human impact on the ecosystem and achieve ecological sustainability.

\subsection{Communicating Environmental CSR}

Many studies in the literature have investigated the effect of CSR communication on consumers. Positive effects of environmental CSR messages on consumer purchase intention were constated [28-30]. Ginder, Kwon and Byun [14] find that the communication style of CSR messages matters. Communicating less than (i.e., greenhushing) or just as much as what a corporation is doing (i.e., uniform) leads to high purchase intention among consumers. However, the authors also find that greenhushing stifles socially responsible behavior among consumers. They call for further studies to examine this impact.

Consumer trust has been confirmed as a crucial factor in business relationships. It entails that consumers believe that a company can make its promises and fulfill its obligations [31]. A high level of consumer trust could enhance a firm's competitive advantage [32]. It also plays an important role in the relationship between environmental CSR messaging and acceptance of the CSR claim [30]. In line with this, Pivato, Misani and Tencati [31], and Swaen and Chumpitaz [33], find that consumer perception of CSR performance is positively related to trust.

In addition to consumer trust, environmental CSR communication may also affect consumer behavior. Copeland [34] coins the term "buycott" as the act of consumers rewarding companies for behavior that is wished for by supporting and purchasing products. For example, the mobile app Buycott was launched to enable consumers to "reward" companies with good CSR practices by investing money in them over the competition [35]. The app enables a consumer to scan any product and trace it back to a company and its socioenvironmental performance; it also suggests alternative brands to purchase from in case a product is linked to a company with problematic environmental or social practices [36].

Another concept describing a consumer's affiliation with brands is consumer social responsibility (CnSR). It entails consumers' engagement in and responsiveness to a company's socially responsible behavior regarding consumption [16]. The literature emphasizes that CnSR still needs to be recognized in light of other active engagements in behavioral change apart from purchase intention [16,17,37]. Boyd, McGarry and Clarke [11] propose the concept of consumer CSR activism and differentiate it from passive activism, such as "liking" the activities of a company publicly. They state that CnSR also refers 
to consumers' active activism, such as creating content in support of a company's CSR activities (i.e., consumer advocacy). Similarly, Du, Bhattacharya and Sen [38] claim that advocacy goes beyond transactional benefits and relates to a long-term consumer-company relationship. Baskentli, Sen, Du and Bhattacharya [39] find that when CSR messages are group-oriented and focus on achieving collective welfare, consumers are likely to commit to advocacy behavior.

This study will consider two types of CSR messages: climate responsibility and sustainable use of natural resources, which Khojastehpour and Johns [21] argue have a group-oriented CSR focus. Schmeltz [18] found that environmental CSR content providing factual information about the company's activities was preferred among consumers over suggestive, visionary content. In comparison to communicating corporate climate responsibility, which may focus on visionary content, addressing sustainable use of natural resources in a corporate advertisement is likely to emphasize factual information, such as the company's commitment to only use renewable energy. Consequently, we conjecture that when a corporate advertisement includes concrete steps for environmental CSR by showing company activities involving sustainable resource utilization, it will lead to higher consumer trust, purchase intention and consumer advocacy, respectively, in comparison to a corporate advertisement containing visionary information addressing the company's responsibility towards the environment. This prediction is summarized in Hypothesis 1.

Hypothesis 1a (H1a). The impact of a corporate advertisement addressing sustainable use of natural resources will be more positive on consumer trust, compared to content addressing climate responsibility.

Hypothesis $\mathbf{1 b} \mathbf{( H 1 b ) . ~ T h e ~ i m p a c t ~ o f ~ a ~ c o r p o r a t e ~ a d v e r t i s e m e n t ~ a d d r e s s i n g ~ s u s t a i n a b l e ~ u s e ~ o f ~}$ natural resources will be more positive on purchase intention, compared to content addressing climate responsibility.

Hypothesis 1c (H1c). The impact of a corporate advertisement addressing sustainable use of natural resources will be more positive on consumer advocacy, compared to content addressing climate responsibility.

\subsection{Message Style}

In the literature, the message style of CSR communication has been studied both conceptually and empirically. Du, Bhattacharya and Sen's [29] framework of CSR communication proposes a few elements that can be manipulated by companies in their messaging, such as "issue", "level of commitment" and "impact" [29]. In terms of the "issue" element, Mueller Loose and Remaud [30] find that consumers presented with a choice between a food product advertised through social claims and one through environmental claims opted for the latter. This implies that environmental issues may be judged by consumers as more urgent to address than social issues.

Ginder, Kwon and Byun [14] develop a model to classify a company's environmental CSR communication into congruent and incongruent communication. Incongruent communication occurs when a company's environmental CSR claim is not in line with its internal environmental CSR actions. Congruent communication occurs when the company describes exactly what sort of action it is taking [14]. The authors differentiate four communication styles: uniform (CSR claims in line with company actions), apathetic (not involved in CSR talk or action), greenhushing (claiming less action than the company is involved in) and greenwashing (claiming more than the company is doing). Uniform and apathetic communication styles can be considered congruent, whereas greenhushing and greenwashing styles are incongruent [14]. The authors found that companies communicating in greenhushing or uniform styles were perceived to be more intrinsically motivated by customers, which led to higher purchase intention [14]. In line with their findings, several scholars conclude that greenwashing can lead to more negative consequences for companies due to attributed extrinsic corporate motives and inconsistent corporate rhetoric and action $[40,41]$. For example, it creates distrust and increased skepticism towards a 
brand [41,42]. Additionally, it can lower consumers' perceived integrity of the company and environmental performance [40] and result in lower purchase intention [14,40]. However, even if businesses adhere to a congruent CSR communication, such as adopting a uniform message style, in some cases it can still lower consumers' positive attitude towards a brand [43]. This phenomenon is tied to negative attribution theory, which suggests that when a company praises itself for green CSR actions, consumers might become skeptical and instinctively attribute negative ulterior motives to them [43]. In this study, we follow Ginder, Kwon and Byun [14] to argue that greenhushing and uniform message styles will have a stronger impact on consumer trust, purchase intention and consumer advocacy, compared to greenwashing. As the apathetic style implies a company not committing to CSR at all, it does not fit the research scope of this study on environmental CSR and was thus left out of the research. This prediction is summarized in Hypothesis 2.

Hypothesis 2a (H2a). A greenhushing or uniform message style of environmental CSR communication will have a more positive impact on consumer trust, compared to a greenwashing message style.

Hypothesis $\mathbf{2 b} \mathbf{b} \mathbf{H} \mathbf{2 b})$. A greenhushing or uniform message style of environmental CSR communication will have a more positive impact on purchase intention, compared to a greenwashing message style.

Hypothesis 2c (H2c). A greenhushing or uniform message style of environmental CSR communication will have a more positive impact on consumer advocacy, compared to a greenwashing message style.

\subsection{Praise Tactics}

Ginder, Kwon and Byun [14] express a need for studies examining various rhetorical styles of CSR messaging and how manipulating them can impact consumer behavior. As an example, in research about CSR as aspirational speech, Christensen, Morsing and Thyssen [44] highlight that although it can create gaps between talking and taking action, which may lead to hypocrisy, using aspirational rhetoric styles can foster social change. Additionally, emotional appeals to guilt, respect, anger and pride as rhetorical tools in environmental messaging enhance consumers' intentions to make sustainable consumption choices [45]. In particular, appealing to consumers' pride is a common approach to formulate CSR messages, as the sense of pride evoked by past sustainable purchases can lead to repeated, sustainable consumption choices [46]. Onwezen, Bartels and Antonides [47] conclude that pride displayed by consumers due to making sustainable purchases has a positive impact on consumption patterns.

Kouchaki and Jami [19] find that when a message is framed to praise consumers for good deeds, they tend to show more self-indulgent behavior in purchasing. This is caused by the fact that such a message focuses more on self-interest (i.e., consumers' direct or indirect contribution to the good deed) rather than altruistic interest, which will lead to consumers' enhanced self-concept and further decrease their propensity for altruistic behaviors. Instead, when a message is framed around praising the company for its social actions, consumers tend to make more altruistic choices and opt for the greener of the two offered products [19]. This phenomenon of purchase as a manifestation of altruism was also discovered by Romani and Grappi [48], who found that displaying companies' positive actions led to perceived moral elevation among consumers and increased their prosocial behavior in terms of donating money to, as well as volunteering for, a cause the company advocated for. Using company praise to appeal to a consumers' altruistic motives could possibly also develop into trust in and advocacy for a company whose green product is being purchased. A study by Du, Bhattacharya and Sen [49] shows that companies who explicitly communicate their role in social initiatives are met with heightened levels of trust among consumers, which functions as a generator for other positive endorsements of the brand, such as advocacy through word-of-mouth or heightened purchase intention. 
In line with these findings in the presented literature, when communicating environmental CSR, company-praising may have a more positive impact on a customer's trust, intention to purchase a green product and advocacy for the company, compared to consumer-praising. Hence, the third set of hypotheses is formulated as follows:

Hypothesis 3a (H3a). Corporate praising in environmental CSR communication has a more positive impact on consumer trust, compared to consumer praising.

Hypothesis $\mathbf{3 b} \mathbf{b} \mathbf{H} \mathbf{3 b})$. Corporate praising in environmental CSR communication has a more positive impact on consumer purchase intention, compared to consumer praising.

Hypothesis $3 \mathbf{c}(\mathbf{H} 3 \mathbf{c})$. Corporate praising in environmental CSR communication has a more positive impact on consumer advocacy, compared to consumer praising.

\subsection{CSR Motives}

According to Ginder, Kwon and Byun [14], the way a CSR message is communicated and its impact on purchase intention is moderated by perceived CSR motives. This entails whether, from a consumer perspective, companies are rather intrinsically motivated to engage in CSR, or whether their motives are extrinsic. Intrinsic motives entail a company acting because of beliefs, values and altruistic reasons, whereas extrinsic motives stem from outside factors, such as increasing profit or stakeholder pressure [50]. In her study on consumer-oriented CSR communication, Schmeltz [18] finds that consumers believe a company engages in CSR for both intrinsic and extrinsic reasons. She concludes that consumers' perceptions that companies do not only engage in CSR for purely altruistic reasons may not automatically lead to negative perceptions of such companies. At present, consumers often acknowledge that CSR engagement can be beneficial to the company and society simultaneously [18]. As the values of attributed intrinsic and extrinsic corporate motives are addressed in the literature, we predict that both types of motives can vary the impact of CSR communication on consumer trust, purchase intentions and consumer advocacy. This prediction is summarized in $\mathrm{H} 4$.

Hypothesis $4 \mathbf{a}(\mathbf{H 4 a})$. Attributed intrinsic and extrinsic corporate motives moderate the impact of message content on consumer trust, purchase intentions and consumer advocacy.

Hypothesis $4 \mathbf{b} \mathbf{( H 4 b )}$. Attributed intrinsic and extrinsic corporate motives moderate the impact of message style on consumer trust, purchase intentions and consumer advocacy.

Hypothesis $4 \mathbf{c}(\mathbf{H} 4 \mathbf{c})$. Attributed intrinsic and extrinsic corporate motives moderate the impact of praise tactics on consumer trust, purchase intentions and consumer advocacy.

The proposed hypotheses are summarized in the conceptual model in Figure 1. 


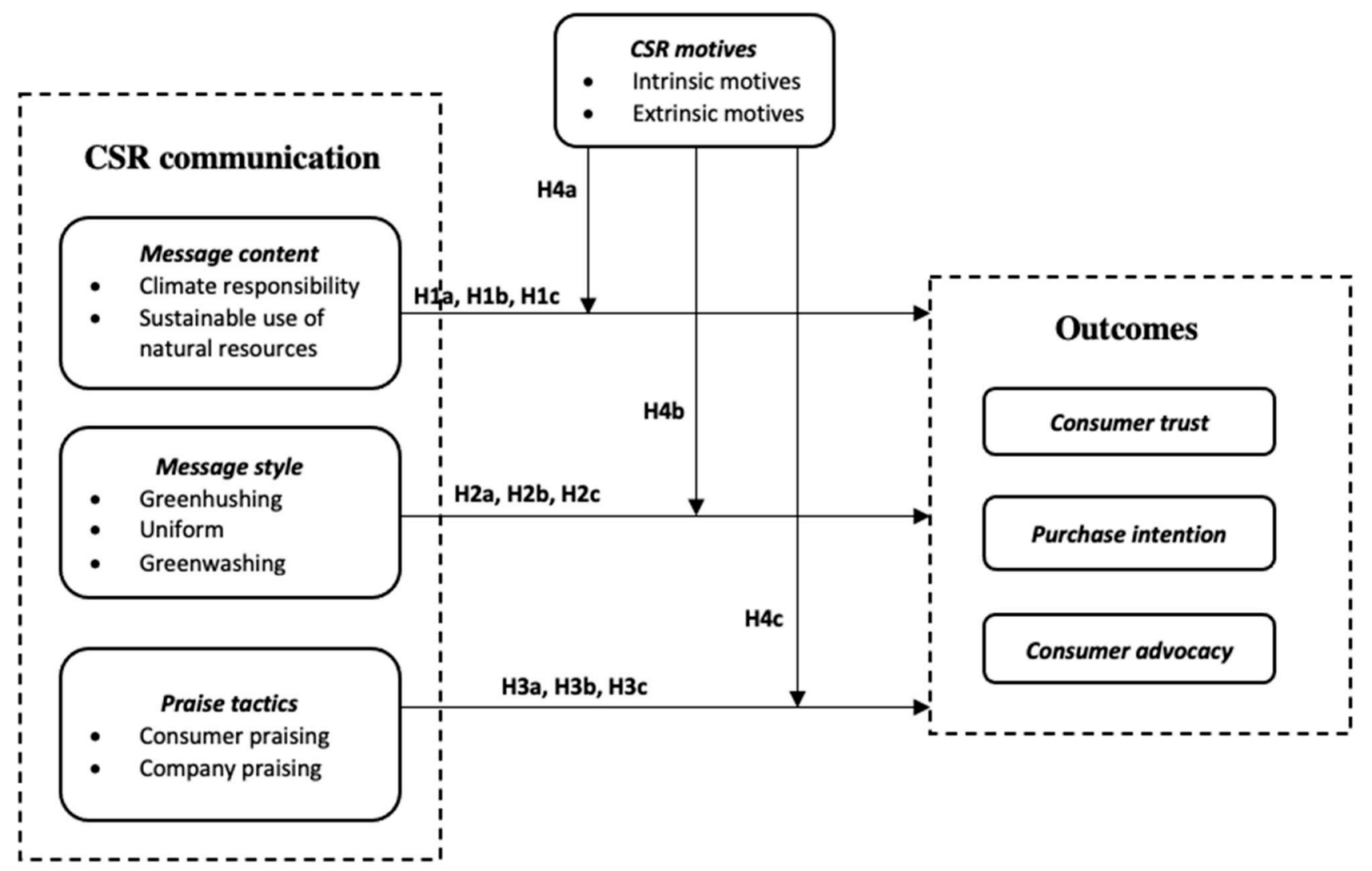

Figure 1. Conceptual model.

\section{Method}

\subsection{Participants}

Data collection occurred between 1 April 1 and 7 April 2020 through Amazon Mechanical Turk and gathered 304 valid respondents. Participants were randomly assigned to one of the experiment conditions, resulting in around 30 participants per condition. Each respondent was paid $0.15 €$ as an incentive for their participation. The final sample consisted of 189 male $(62.2 \%)$ and 115 female (37.8\%) respondents. Among them, the majority obtained a Bachelor's (56.9\%) or a Master's degree (25.3\%). Additionally, $14.1 \%$ obtained a high school diploma as their highest level of education and 3.6\% obtained a Ph.D., doctoral or associate degree. The majority of participants originated from the U.S. (44.1\%), followed by India $(30.3 \%)$. Regarding age $(\mathrm{M}=34.5, \mathrm{SD}=10.6), 45.1 \%$ of participants were aged 17 to $30,41.4 \%$ were aged 31 to 45 and $13.5 \%$ were aged 45 to 69 , indicating a relatively young sample.

\subsection{Stimuli}

The experimental design included two types of message contents (climate responsibility vs. sustainable use of natural resources), three message styles (greenhushing vs. uniform vs. greenwashing) and two praise tactics (corporate praising vs. consumer praising). Since the greenhushing communication style entails that companies do not advertise their environmental activities, these conditions did not include any CSR message content. This resulted in 10 conditions in total. A pre-test was conducted among a group of university students to understand whether the 10 conditions can be clearly distinguished. Their feedback was incorporated into the final experiment stimuli.

The fictitious Dutch tea brand "HerbaLove" was created for this study. A Facebook "About" page, an independent, third-party NGO report about their environmental CSR activities and a HerbaLove advertisement were presented to participants. The choice of advertising posters as a means to convey praise tactics and environmental message 
content is based on the fact that participants would naturally encounter these messages in an advertising context as well. Moreover, working with a fictitious brand can help mitigate any perceived bias in relation to brand familiarity. For each experiment condition (see examples in Figure 2), respondents reviewed the three HerbaLove documents. The design of these stimuli was inspired by past research concerning environmental CSR communication [14], as well as existing environmental CSR advertisements created by companies such as Unilever and Douwe Egberts, two umbrella brands that own several international tea brands.

1. About Herbalove

The Dutch tea company HerbaLove has previously communicated environmental CSR activities and attitudes through marketing and PR; especially advertisements and social media campaigns.

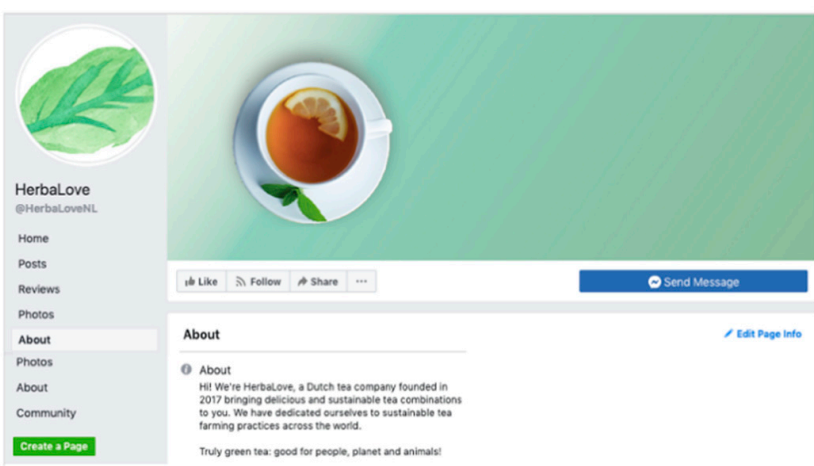

2. Environmental CSR report for HerbaLove by independent NGO Slow Food International

“Herbalove recognizes the challenge of climate change throughout its production and distribution chain, highlighting that stakeholders are increasingly interested in the food source and how it was produced. HerbaLove is aware that companies like them need to take responsibility for a range of climate-related issues such as deforestation, animal welfare and biodiversity. The company also identifies that climate change impacts through flooding and droughts that lead to loss of ecologically and agriculturally valuable soils. Therefore, they are diminishing unsustainable tea farming practices that may have serious repercussions on the environment.

Since 2017, HerbaLove sources all of its tea bags from Rainforest Alliance Certified ${ }^{\top M}$ farms. The partnership with the Rainforest Alliance, an international environmental organization, ensures that all the farms are certified concerning sustainable farm management, covering social, economic and environmental aspects. By the end of 2019, about $80 \%$ of HerbaLove Organic Green Tea bags sold in Western Europe were sourced from Rainforest Alliance Certified ${ }^{T M}$ farms. Moreover, HerbaLove set up a public-private partnership project in 2015 with several international partners to train smallholder farmers in Kenya about sustainable tea cultivation."

(Slow Food International, 2020)

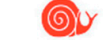

Slow $\mathrm{Food}^{\circ}$

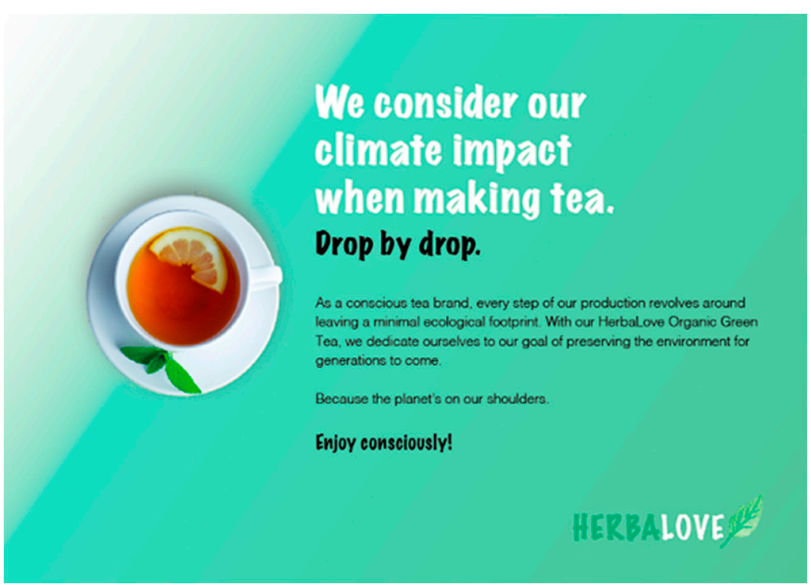

(a)
1. About Herbalove
The Dutch tea company HerbaLove has previously communicated environmental CSR activities and attitudes through marketing and PR; especially advertisements and social media campaigns.

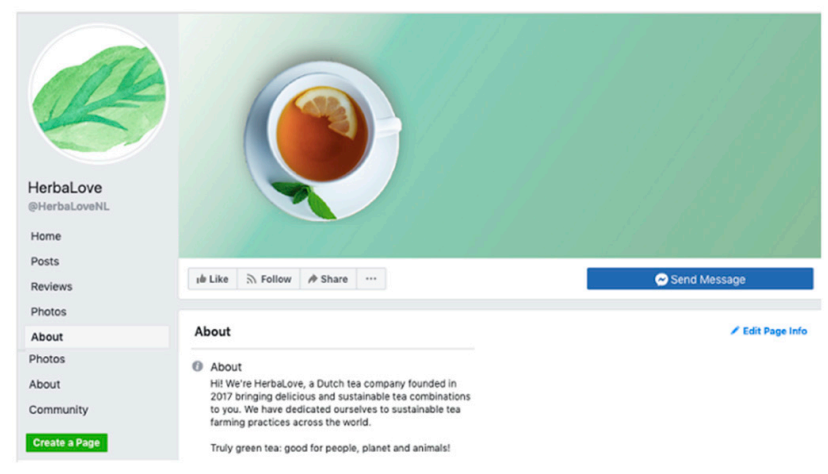

2. Environmental CSR report for HerbaLove by independent NGO Slow Food International

"HerbaLove's environmental CSR policy contains many gaps.

Only $15 \%$ of the company's tea blend is Rainforest Alliance Certified ${ }^{\mathrm{TM}}$, and the company hasn't expressed any motivations to increase this percentage, which is in fact quite low compared to the percentages of other tea brands' blends. Partnerships with suppliers and distributors to work on a more sustainable and carbon-neutral way of sourcing and distributing tea could not be distinguished.

Herbalove unfortunately does not provide its stakeholders with an annual report discussing their climate footprint, making it difficult to nearly impossible to distinguish whether company emissions rise or fall from year to year.

When it comes to the packaging of their products, Herbalove does not provide a percentage of packaging sourced from recycled materials, nor does it state whether the packaging is renewable or not, or whether it is working toward a concrete goal in this area.

In conclusion, HerbaLove's environmental CSR conduct needs to be expanded in order to call the brand environmentally conscious. Many factors are left unaddressed and their policy remains nontransparent and unconcise."

(Slow Food International, 2020)

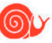

Slow Food

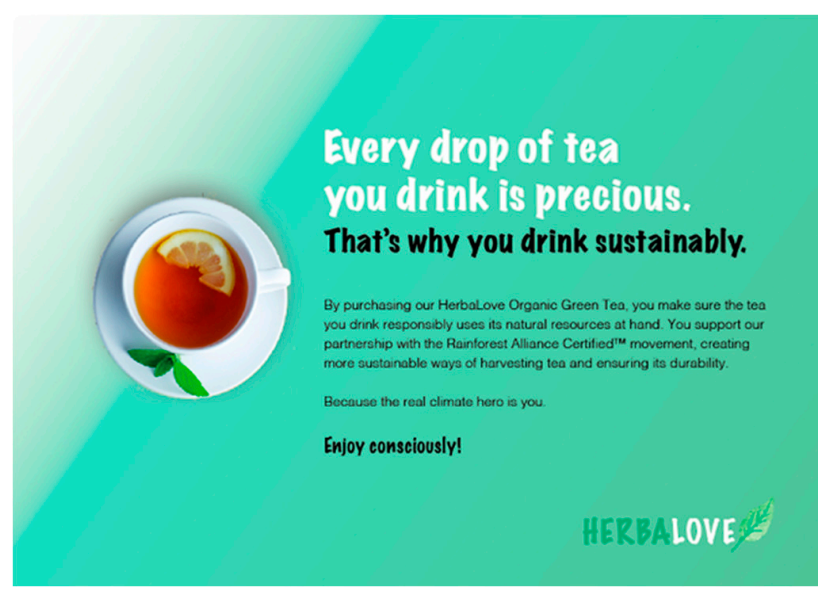

(b)

Figure 2. Examples: experiment conditions: (a) Message content (climate responsibility) x message style (uniform) x praise tactics (corporate praise); (b) Message content (sustainable use of natural resources) $\mathrm{x}$ message style (greenwashing) x praise tactics (consumer praise). 
The experiment conditions were randomly assigned to each participant. The online survey designed in Qualtrics consists of seven sections, starting with introducing participants to the study and presenting them the Consent Form. Then, participants were asked whether they have a Facebook account and drank tea, which were two criteria for selecting valid respondents. Next, the stimulus material was presented. Participants were randomly assigned to one of the ten conditions, including a screenshot of the HerbaLove Facebook "About" section, a screenshot of an environmental CSR report for HerbaLove, written by a fictitious NGO Slow Food International, as well as an advertisement presenting one of HerbaLove's tea blends. Directly after exposure, participants had to indicate their level of purchase intention, trust in and potential advocacy for the brand. Further, attributed intrinsic and extrinsic corporate motives were measured. The survey ended with two manipulation check questions and asked for demographic information such as gender, age, level of education and country of origin and residence.

\subsection{Measurements}

The dependent variables and moderators were all measured through validated scales in the literature. Table 1 shows an overview of all measurements used for this study. For measuring consumer trust ( $\alpha=0.93$ ), a validated three-item scale in Pivato, Misani and Tencati [31] was adopted. Purchase intention was measured using the statement "I would buy this product". Consumer advocacy $(\alpha=0.82)$ was measured through four items, combining the three-item scale in Du, Bhattacharya and Sen [38], which assesses attitudes towards CSR communication among consumers, and one item capturing online dimensions of consumer CSR activism developed by Boyd, McGarry and Clarke [11]. The scales to measure attributed intrinsic and extrinsic corporate motives were retrieved from Vlachos, Panagopoulos and Rapp [50]. Attributed intrinsic corporate motives $(\alpha=0.90)$ and extrinsic corporate motives $(\alpha=0.80)$ each contained three items. All statements were adapted to the context of environmental CSR. The three dependent variables and two moderators were all measured using five-point Likert scales ranging from "strongly disagree" to "strongly agree".

Table 1. Measurements of dependent variables and moderators.

\begin{tabular}{|c|c|}
\hline Variables & Measurements \\
\hline Consumer trust & I trust HerbaLove. You can always count on HerbaLove. HerbaLove is reliable. \\
\hline Purchase intention & I would buy this product. \\
\hline Consumer advocacy & $\begin{array}{l}\text { I would like to try new products introduced under this brand name. } \\
\text { I talk favorably about this brand to friends and family. } \\
\text { If the maker of this brand did something I didn't like, I would be willing to give it } \\
\text { another chance. } \\
\text { If I end up liking a product of this company, I will discuss it on social networks. }\end{array}$ \\
\hline Attributed intrinsic corporate motives & $\begin{array}{l}\text { HerbaLove is genuinely concerned about being socially responsible. } \\
\text { HerbaLove engages in socially responsible initiatives because it feels morally } \\
\text { obligated to help. } \\
\text { HerbaLove engages in socially responsible initiatives in order to give back something } \\
\text { to the community. }\end{array}$ \\
\hline Attributed extrinsic corporate motives & $\begin{array}{c}\text { HerbaLove engages in socially responsible initiatives in order to get more customers. } \\
\text { HerbaLove engages in socially responsible initiatives because it feels competitive } \\
\text { pressures to engage in such activities. } \\
\text { HerbaLove hopes to increase its profits by engaging in socially responsible initiatives. }\end{array}$ \\
\hline
\end{tabular}

We conducted a confirmatory factor analysis (CFA) to assess the measurement quality. The Chi-square statistic indicated an imperfect fit $\left(\chi^{2}=115,884, \mathrm{df}=59, p<0.001\right)$. Despite this, the CFI (0.981), TLI (0.975), NFI (0.962), and RMSEA value (0.056) all suggested a good model fit. Also, all factor loadings were above 0.80 and significant. The average variance extracted (AVE) of all scales greater than 0.50 and greater than their shared 
variances with the other scaled confirmed the convergent and discriminant validity of the measurements [51].

\subsection{Manipulation Check}

Two manipulation checks were conducted for message style and praise tactics, respectively. Both manipulation checks were successful with $95 \%$ certainty $\left(\chi^{2}\right.$ message style $(4, \mathrm{~N}=304)=28.79, p<0.001 ; \chi^{2}$ praise $\left.(1, \mathrm{~N}=304)=19.74, p<0.001\right)$. As the differences in the two scenarios for message content were straightforward, no manipulated questions were included in the survey. Despite this, the successful manipulation of message style and praise tactics implies that the respondents read the two scenarios for message content carefully.

\section{Results}

To test the hypotheses, we first conducted a three-way multivariate analysis of variance (MANOVA) with message content, message style and praise tactics as fixed factors, and consumer trust, purchase intention and consumer advocacy as dependent variables. The results indicated significant main effects of the message style, Wilks' $\lambda=0.809, \mathrm{~F}(3,292)=22.95$, $p<0.001, \eta^{2}=0.19$, but insignificant main effects for message content, Wilks' $\lambda=0.982$, $\mathrm{F}(3,292)=1.77, p=0.152, \eta^{2}=0.02$ and praise tactics, Wilks' $\lambda=0.987, \mathrm{~F}(3,292)=1.29$, $p=0.277, \eta^{2}=0.01$. No significant interaction effect was found between message content, message style and praise tactics on the three dependent variables.

\subsection{Message Content}

One-way ANOVAs were conducted to test H1. For consumer trust, no significant statistical difference was found between the groups: $F(1,247)=3.80, p=0.081, \eta^{2}=0.02$. This implies that there was no difference in consumer trust between the group exposed to climate responsibility and the group exposed to sustainable use of natural resources. For purchase intention, no significant difference was found either: $\mathrm{F}(1,247)=2.11, p=0.148$, $\eta^{2}=0.01$. A similar insignificant result was found for consumer advocacy, $F(1,247)=3.49$, $p=0.063, \eta^{2}=0.01$. Hence, H1a to H1c was rejected, despite participants belonging to the sustainable resources group scoring slightly higher on trust, purchase intention and advocacy compared to their climate responsibility counterparts.

\subsection{Message Style}

One-way ANOVAs were conducted to test H2. For consumer trust, a large and significant difference was detected between the groups: $F(2,301)=26.41, p<0.001$, $\eta^{2}=0.15$. There was a significant difference between the greenhushing and greenwashing groups $\left(\mathrm{M}_{\text {difference }}=0.70, p<0.001\right)$, as well as the uniform and greenwashing groups $\left(\mathrm{M}_{\text {difference }}=-0.85, p<0.001\right)$. No significant difference was found between the greenhushing and uniform groups. Hence, H2a was accepted as participants exposed to the greenhushing and uniform messages showed higher trust levels compared to those exposed to the greenwashing group.

For purchase intention, there was a large significant difference between the groups: $\mathrm{F}$ $(2,301)=29.47, p<0.001, \eta^{2}=0.16$. A post-hoc Tukey HSD test showed significant differences between greenhushing and greenwashing message styles $\left(\mathrm{M}_{\text {difference }}=0.67, p<0.001\right)$, as well as between uniform and greenwashing styles $\left(\mathrm{M}_{\text {difference }}=-0.86, p<0.001\right)$. No significant difference was found between the uniform and greenhushing groups. Hence, $\mathrm{H} 2 \mathrm{~b}$ was accepted. Consumers exposed to greenhushing or uniform environmental CSR messages were far more likely to purchase the advertised product compared to participants in the greenwashing group, with uniform message group participants indicating the highest purchase intention.

For consumer advocacy, a moderately significant difference was found between groups: $F(2,301)=10.61, p<0.001, \eta^{2}=0.07$, with a significant difference only between uniform and greenwashing message styles $\left(\mathrm{M}_{\text {difference }}=-0.51, p<0.001\right)$. Hence, 
H2c was partially accepted as only the participants exposed to the uniform message style indicated statistically higher advocacy, compared to the greenwashing group. Despite this, it is worth mentioning that participants in the greenhushing group indicated higher advocacy compared to those in the greenwashing group.

\subsection{Praise Tactics}

For consumer trust, the ANOVA results showed no significant difference between the two groups: $F(1,301)=0.81, p=0.386, \eta^{2}<0.01$. In other words, it did not matter whether participants were exposed to consumer praise or company praise. Hence, H3a was rejected. Similarly, for purchase intention, there was no statistically significant difference between the company and consumer praise groups: $F(1,302)=0.98, p=0.324, \eta^{2}<0.01$. Participants exposed to consumer praise were almost just as likely to purchase the product as participants experiencing company praise. $\mathrm{H} 3 \mathrm{~b}$ was therefore rejected. For consumer advocacy, there was no significant difference between the company and consumer praise type groups: $\mathrm{F}(1,302)=2.69, p=0.102, \eta^{2}=0.01$. Participants exposed to consumer praising indicated an almost equally high advocacy rate as participants exposed to company praise. Hence, $\mathrm{H} 3 \mathrm{c}$ was also rejected.

\subsection{Moderation Effects}

In order to examine the moderation effects of attributed intrinsic and extrinsic corporate motives, multiple linear regression analyses were conducted. All continuous variables were standardized before conducting the analyses.

First, a set of multiple regressions was used to examine whether attributed intrinsic and extrinsic corporate motives had a moderating effect on the relationship between message content and consumer trust, purchase intention and consumer advocacy. H4a had to be rejected, as no moderation occurred. We only observed direct impacts of perceived intrinsic motives on consumer trust $(b=0.79, p<0.001)$, purchase intention $(b=0.57, p<0.001)$ and consumer advocacy $(b=0.75, p<0.001)$. We did not observe any significant direct effect of attributed extrinsic corporate motives or message content on the dependent variables.

Next, when testing the moderation effects on the relationship of message style and consumer trust (see Table 2), we found a significant interaction effect between message style and attributed intrinsic corporate motives $(b=0.30, p<0.001)$. Similarly, a strong moderation effect between message style and intrinsic motives was found in the purchase intention model $(b=0.40, p<0.001)$. In addition, a modest moderation effect between message style and intrinsic motives was detected on consumer advocacy $(b=0.19, p=0.034)$. Figure 3 shows the moderation effects with low, medium and high attributed intrinsic corporate motives. One standard deviation above or below the mean was used to indicate the thresholds for a high or low score in the figure. In contrast to intrinsic motives, we did not find any moderation effect of attributed extrinsic corporate motives on the three dependent variables. Hence, H4b was only partially confirmed.

Table 2. Moderation effects of perceived corporate motives $(\mathrm{N}=304)$.

\begin{tabular}{cccc}
\hline & CONSUMER TRUST & PURCHASE INTENTION & CONSUMER ADVOCACY \\
\hline & $b$ & $b$ & $B$ \\
\hline CONSTANT & $0.12^{*}$ & $0.23^{* *}$ & -0.12 \\
\hline MESSAGE STYLE & -0.04 & $-0.12^{*}$ & $0.09^{*}$ \\
\hline INTRINSIC MOTIVES & $0.58^{* * *}$ & $0.32^{* *}$ & $0.62^{* * *}$ \\
\hline EXTRINSIC MOTIVES & $0.15^{*}$ & 0.04 & $0.21^{* *}$ \\
\hline STYLE X INTRINSIC & $0.30^{* * *}$ & $0.40 * * * 19^{*}$ \\
\hline STYLE X EXTRINSIC & -0.11 & $<-0.01$ & -0.09 \\
\hline$R^{2}$ & 0.79 & 0.56 & 0.67 \\
\hline$F$ & 227.17 & 78.37 & 123.40 \\
\hline Note: Significance levels: ${ }^{*} p<0.05, * * 0.01, * * *<0.001$. &
\end{tabular}




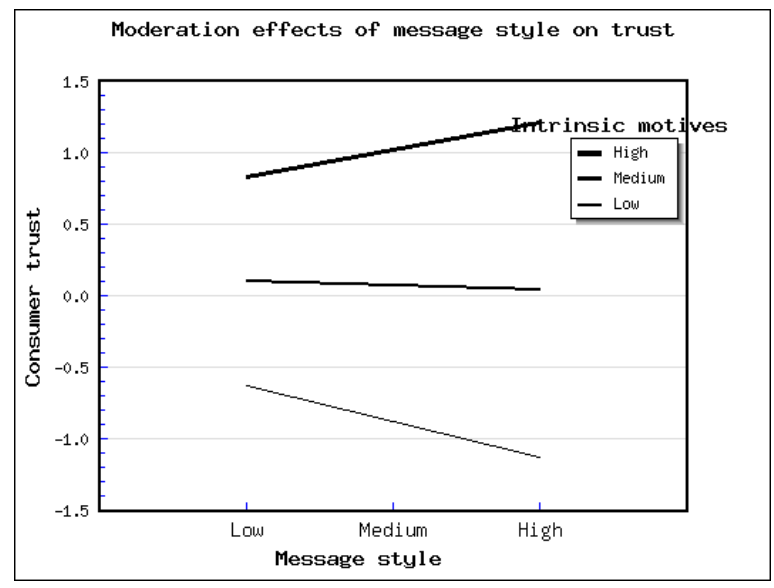

(a)

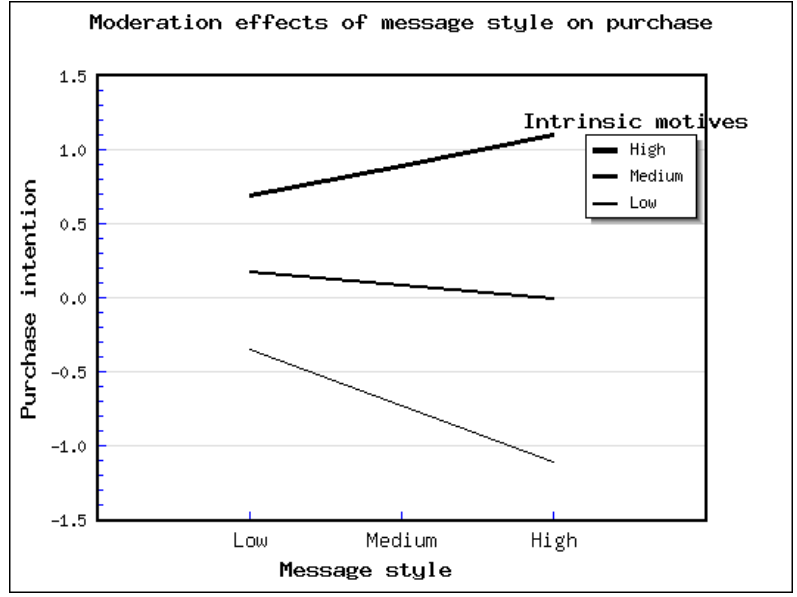

(b)

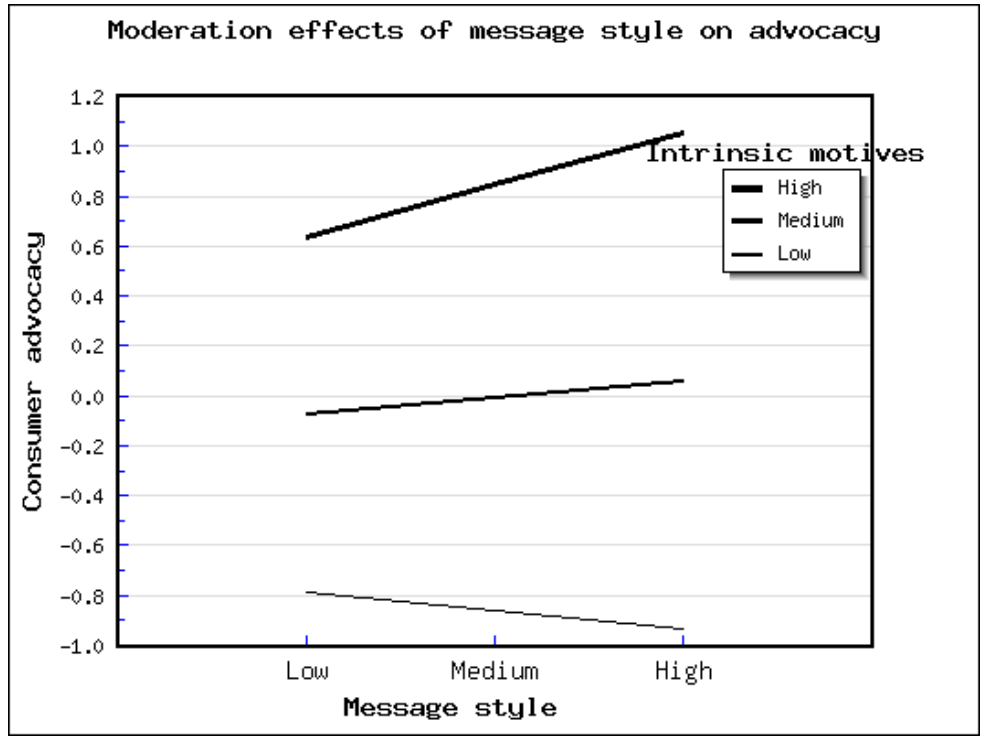

(c)

Figure 3. Moderation effects of perceived corporate intrinsic motives for (a) message style on trust, (b) message style on purchase intention, (c) message style on advocacy.

Furthermore, we tested the moderation effects on the relationships of praise tactics and three dependent variables, respectively. No moderation effect was found for perceived intrinsic motives or extrinsic motives. Hence, $\mathrm{H} 4 \mathrm{c}$ was rejected.

\section{Discussion}

\subsection{Theoretical Implications}

This study examined to what extent message content, message style and praise tactics in environmental CSR communication affect consumer trust, purchase intention and consumer advocacy, respectively. The results confirmed our hypothesis that $\mathrm{CnSR}$ beyond purchase intention can be achieved through a company's environmental CSR communication. We contributed to the CSR literature by examining the three factors in relation to environmental CSR communication within one framework. In the past, these factors were only discussed in separate studies [18].

The rejection of H1 stands in contrast to the findings in Schmeltz [18], which found that CSR content including concrete steps for taking action work better for encouraging consumers to opt for the advertised product. This finding raises questions about the level of nuance in environmental message content and whether companies inciting consumers to 
make green choices and to align with company values are not better off focusing on other factors rather than fine-tuning their claims about how a product is tied to sustainability and climate responsibility.

Accepting the prediction in $\mathrm{H} 2$ confirms an array of past research that found environmental CSR communication can have a positive impact on purchase intention [28-30] and consumer trust [29,31,33]. It also confirms the finding in Ginder, Kwon and Byun [14] that greenhushing and uniform message styles both work better than greenwashing in terms of generating support among consumers. Our results coincide with a few studies examining greenwashing communication strategies, which discovered that it could lead to stakeholder skepticism [40-42]. Our results did not provide any confirmatory data on negative attribution theory, which occurs when companies adhering to their environmental CSR standards communicate such claims [43]. Furthermore, we contributed to the literature by investigating CnSR beyond purchase intention and tied this concept to consumer advocacy for a brand. It filled the call for assessing CnSR beyond a unidimensional concept $[16,17,37]$.

Our consideration of praise tactics in the study is in line with the call in Ginder, Kwon and Byun [14] for more research examining various rhetorical styles in CSR communication. Although no significant difference was detected, our results show a clear pattern that participants exposed to consumer praise were more likely to trust the brand than others exposed to company praise. This finding opposes the observation in Romani and Grappi [48] and Kouchaki and Jami [19], who found that a message framed around praising the company of a product led to consumers making altruistic choices; hence, consumers were more favorable towards the green product and the company trying to address climate change. However, the rejection of $\mathrm{H} 3$, and hence the non-significant effect of praise tactics, does not imply the general irrelevance of other rhetorical tactics, such as aspirational talk [44] or emotional appeals to guilt, anger, respect or pride [45].

Furthermore, when examining the moderation effects of attributed intrinsic and extrinsic corporate motives, we found that the extent to which consumers believed the brand was engaging in CSR activities for intrinsic reasons was a direct predictor for trust level, purchase intention and consumer advocacy. Additionally, we confirmed with $\mathrm{H} 4 \mathrm{~b}$ that attributed intrinsic corporate motives moderate the relationships of message style and the three dependent variables. This result confirms the finding in Ginder, Kwon and Byun's theoretical model [14], whereas the significant moderation effect on consumer advocacy contributes a new insight to the literature. In terms of attributed extrinsic corporate motives, although Schmeltz [18] argued that consumers may acknowledge that CSR engagement can be beneficial to the company, our findings do not support any of the proposed moderation effects predicting the value of extrinsic motives.

\subsection{Managerial Implications}

At present, companies walk a complex line between gaining credibility and inducing skepticism in consumers when it comes to communicating environmental CSR activities. This study provided insightful results regarding the circumstances under which environmental CSR messages can be effective if a corporation's goal is to generate consumer support for corporate efforts towards ecological sustainability and indulging in eco-friendly consumption choices.

To create a sense of trust and enable consumer advocacy, synchronizing what is being communicated with a company's actual environmental CSR actions and adopting a uniform message style is an effective strategy. Furthermore, this study revealed that the aspects of environmental CSR actions and the use of praise tactics are of secondary importance. Moreover, we found that consumers affiliate more with companies they perceive as intrinsically motivated to engage in environmental CSR actions, though they do acknowledge that companies can profit from environmental CSR activities. A company that strongly develops intrinsic values for the betterment of the environment is likely to gain consumers' trust and support. Rather than focusing on which praise tactics to use or what CSR content to emphasize, it is more rewarding for companies to work on action-message 
congruency, transparency and the formulation of intrinsic or extrinsic motives, as these building blocks will organically lead to an effective environmental CSR message.

In line with past research on environmental CSR communication styles [14,41,42], this study makes a strong case for refraining from using greenwashing techniques, as they seem to be the least effective message style for attaching consumers to a product or company. In particular, when consumers are provided with evidence that a company's actions and messages are incongruent, lower trust levels, purchase intention and consumer advocacy will develop. In addition, when non-governmental organizations and individuals are fueled by the social media landscape and start to behave as watchdogs over corporate actions, any incongruence in a company's CSR communication can be revealed. Hence, having a truthful and transparent approach to tackling environmental responsibilities rewards companies in that it protects them from being criticized.

Additionally, it is beneficial for companies to synchronize their environmental CSR actions and communication, as it can help a company establish long-term bonds with consumers beyond purchase intention in a way where consumers could assist a company with its ambitions to contribute to sustainability. In light of the ongoing climate debate, our findings regarding consumer advocacy may motivate companies to pursue their sustainable goals, as consumers will walk this path together with them. CSR and CnSR can go hand in hand, as they raise each other's standards for how ecological sustainability is best achieved [17].

\section{Conclusions}

This paper aimed to gain insights into how the communication of environmental CSR can affect consumer trust, purchase intention and advocacy. By conducting an online experiment, the impact of the three CSR communication factors-message content, message style and praise tactic - were assessed. Several conclusions can be drawn from the current study. First, with an effective communication strategy, environmental CSR can create consumer affiliation with a product or company on a deep level, such as stimulating consumer advocacy. Our findings suggest that CnSR should not be treated as a unidimensional concept. Instead, consumer advocacy could be considered as an integral part of it, in addition to purchase intention. In order to achieve effective CSR communication, companies need to adopt a uniform communication style, entailing the synchronization of a company's environmental CSR actions and messages. This message style was found to be most effective and stands in strong contrast to the adoption of greenwashing techniques, which caused negative repercussions among consumers exposed to it. Furthermore, a company's level of perceived intrinsic motivation to engage in a CSR cause can strengthen the impact of CSR communication on consumer attitudes and behaviors, indicating that CSR communication aimed at creating a frame of intrinsic motivation will not only convince consumers to purchase a product but also generate trust and even deeper affiliation with the company. In summary, our results imply that corporate sustainability missions can be better achieved when companies walk the path of environmental CSR together with consumers by practicing transparency, demonstrating message congruency and developing intrinsic aspirations for the involved environmental CSR cause.

Several limitations of the research process need to be addressed. First, in the experiment conditions that included an advertisement demonstrating sustainable use of natural resources, participants were informed that HerbaLove partnered up with the Rainforest Alliance Certified ${ }^{\mathrm{TM}}$ program in order to ensure the sustainable resourcing of tea and water use. This may have had an enhancing effect on the perceived credibility of the company because there was a partnership with an NGO involved. This potential bias was not accounted for during the research process. Similarly, the use of advertisement posters as a means by which to convey environmental messaging strategies during the experiment may have led to potential bias among participants. This is due to the fact that advertising has the aim to convince or persuade audiences and hence may have had a confounding effect on the results. Furthermore, similar to Ginder, Kwon and Byun [14], this research used a fictitious 
company and product to test three independent variables: CSR advertisement, message style and praise tactics. This might have created a mental distance between participants' attitudes and behaviors when encountering an environmental CSR message in real life, as well as their responses to the questions during the experiment, and hence may have had an impact on the external validity of the study. The rejection of the hypotheses (e.g., H1 and $\mathrm{H} 3$ ) might be related to the experiment design as well. Although the experiment conditions were successfully manipulated, more detailed information about the brand and its CSR activities could be included in the stimuli in order to further distinguish the message style and praise tactics conditions. Moreover, it must be pointed out that the data for this study was collected using the online recruitment platform Amazon MTurk. As Wright [52] stated, researching online audiences inhibits the researcher from verifying whether respondents replied to questions truthfully as can be done when conducting face-to-face research, which might have resulted in a self-reporting bias among participants. As Berinsky, Huber and Lenz [53] stated, over time, Amazon MTurk respondents may have learned to habitually respond to questionnaires and anticipate the researcher's preferred answers.

The results of this study have painted a more concise picture of which environmental CSR message strategies are most effective when it comes to gaining a consumer's trust and advocacy, as well as inciting them to make more environmentally conscious purchase decisions. Nevertheless, they have also sparked some new ideas and concepts, which need to be added to the equation and explored in future research. Firstly, future studies can consider a participant's level of environmental concern when studying environmental CSR communication, as it might alter the latter's impact on consumer attitudes and behaviors. Scholars can delve into the relationship of individuals' sensitivity to environmental issues and environmental CSR communication techniques and explore how these attributes can benefit the advertisement of eco-friendly products or brands. Secondly, future research can examine to what extent including different types of collaboration with NGOs into an advertisement affects consumer perceptions of the company and the product. For example, Wang and Holznagel [54] argue that partnering with NGOs is more likely to stimulate consumers' support in comparison to sponsorships. Future research can examine whether such a difference holds in terms of communicating environmental CSR. Lastly, the concept of consumer advocacy needs to be extended and examined in the context of online social networking sites. Future research can dedicate itself to exploring the different ways in which consumers show their advocacy of a company on social networks, and how these behaviors tie into activism inspired by corporate rhetoric and action in relation to CSR.

Author Contributions: Conceptualization, J.C. and Y.W.; methodology, J.C. and Y.W.; software, J.C. and Y.W.; validation, J.C. and Y.W.; formal analysis, J.C. and Y.W.; investigation, J.C.; resources, J.C.; data curation, J.C.; writing-original draft preparation, J.C.; writing-review and editing, Y.W. and J.C.; visualization, J.C.; supervision, Y.W.; project administration, Y.W.All authors have read and agreed to the published version of the manuscript.

Funding: This research received no external funding.

Institutional Review Board Statement: Not applicable.

Informed Consent Statement: Informed consent was obtained from all subjects involved in this study.

Data Availability Statement: The data presented in this study are available on request from the corresponding author.

Conflicts of Interest: The authors declare no conflict of interest.

\section{References}

1. UNFCCC. UNSD—Environment Statistics. 2020. Available online: https://unstats.un.org/unsd/envstats/climatechange.cshtml (accessed on 24 March 2021).

2. Borunda, A. See how a Warmer World Primed California for Larger Fires. National Geographic. 15 November 2018. Available online: https:/ / www.nationalgeographic.com/environment/2018/11/climate-change-california-wildfire/ (accessed on 24 March 2021). 
3. Jackson, M. As glaciers disappear, humans lose a lot more than Ice. National Geographic. 26 December 2018. Available online: https: //www.nationalgeographic.com/environment/2018/12/glaciers-disappear-melting-ice-impacts-human-culture-history/ (accessed on 24 March 2021).

4. Wires. WIRES Australian Wildlife Rescue Organisation. 2020. Available online: https://www.wires.org.au/ (accessed on 24 March 2021).

5. Bäckstrand, K.; Lövbrand, E. The road to Paris: Contending climate governance in the post-Copenhagen era. J. Environ. Policy Plan. 2016, 21, 519-532. [CrossRef]

6. Barney, J.B. Why resource-based theory's model of profit appropriation must incorporate a stakeholder perspective. Strateg. Manag. J. 2018, 39, 3305-3325. [CrossRef]

7. Falcone, P.M. Analysing stakeholders' perspectives towards a socio-technical change: The energy transition journey in Gela Municipality. AIMS Energy 2018, 6, 645-657. [CrossRef]

8. Kahupi, I.; Hull, C.E.; Okorie, O.; Millette, S. Building competitive advantage with sustainable products-A case study perspective of stakeholders. J. Clean. Prod. 2021, 289, 125699. [CrossRef]

9. O'Connor, A.; Shumate, M. An economic industry and institutional level of analysis of corporate social responsibility communication. Manag. Commun. Q. 2010, 20,1-23. [CrossRef]

10. Greenpeace. 3 Redenen waarom Protestival Niet Gestopt had Mogen Worden. Protestival Schiphol. 2020. Available online: https: / / www.greenpeace.org/nl/protestival/ (accessed on 24 March 2021).

11. Boyd, E.; McGarry, B.; Clarke, T. Exploring the empowering and paradoxical relationship between social media and CSR activism. J. Bus. Res. 2016, 69, 2739-2746. [CrossRef]

12. Wang, Y.; Berens, G. The impact of four types of corporate social performance on reputation and financial performance. J. Bus. Ethics 2015, 131, 337-359. [CrossRef]

13. Reinhardt, F.; Casadeus-Masanell, R.; Kim, H. Patagonia. Harvard Business School Strategy Unit Case No. 711-020. 19 October 2010. Available online: https:/ / papers.ssrn.com/sol3/papers.cfm?abstract_id=2025181 (accessed on 24 March 2021).

14. Ginder, W.; Kwon, W.; Byun, S. Effects of internal-external congruence-based CSR positioning: An attribution theory approach. J. Bus. Ethics 2019, 169, 1-15. [CrossRef]

15. Tian, Z.; Wang, R.; Yang, W. Consumer responses to corporate social responsibility (CSR) in China. J. Bus. Ethics 2010, 101, 197-212. [CrossRef]

16. Feldman, P.M.; Vasquez-Parraga, A. Consumer social responses to CSR initiatives versus corporate abilities. J. Consum. Mark. 2013, 30, 100-111. [CrossRef]

17. Manning, L. Corporate and consumer social responsibility in the food supply chain. Br. Food J. 2013, 115, 9-29. [CrossRef]

18. Schmeltz, L. Consumer-oriented CSR communication: Focusing on ability or morality? Corp. Commun. Int. J. 2012, 17, 29-49. [CrossRef]

19. Kouchaki, M.; Jami, A. Everything we do, you do: The licensing effect of prosocial marketing messages on consumer behavior. Manag. Sci. 2018, 64, 102-111. [CrossRef]

20. Sodano, V.; Hingley, M. The food system, climate change and CSR: From business to government case. Br. Food J. 2013, 115, 75-91. [CrossRef]

21. Khojastehpour, M.; Johns, R. The effect of environmental CSR issues on corporate/brand reputation and corporate profitability. Eur. Bus. Rev. 2014, 26, 330-339. [CrossRef]

22. WCED. Our Common Future; Oxford University Press: Oxford, UK, 1987; p. 43.

23. Bansal, P. Evolving sustainably: A longitudinal study of corporate sustainable development. Strateg. Manag. J. 2005, 26, 197-218. [CrossRef]

24. Gladwin, T.N.; Kennelly, J.J.; Krause, T. Shifting paradigms for sustainable development: Implications for management theory and research. Acad. Manag. Rev. 1995, 20, 874-907. [CrossRef]

25. Amini, M.; Bienstock, C. Corporate sustainability: An integrative definition and framework to evaluate corporate practice and guide academic research. J. Clean. Prod. 2014, 76, 12-19. [CrossRef]

26. Shrivastava, P. The role of corporations in achieving ecological sustainability. Acad. Manag. Rev. 1995, 20, 936-960. [CrossRef]

27. Morelli, J. Environmental sustainability: A definition for environmental professionals. J. Environ. Sustain. 2011, 1, 1-9. [CrossRef]

28. Lee, K.; Shin, D. Consumers' responses to CSR activities: The linkage between awareness and purchase intention. Public Relat. Rev. 2010, 36, 193-195. [CrossRef]

29. Du, S.; Bhattacharya, C.; Sen, S. Maximizing business returns to corporate social responsibility (CSR): The role of CSR communication. Int. J. Manag. Rev. 2010, 12, 8-19. [CrossRef]

30. Mueller Loose, S.; Remaud, H. Impact of corporate social responsibility claims on consumer food choice. A cross-cultural comparison. Br. Food J. 2013, 115, 142-161. [CrossRef]

31. Pivato, S.; Misani, N.; Tencati, A. The impact of corporate social responsibility on consumer trust: The case of organic food. Bus. Ethics A Eur. Rev. 2008, 17, 3-12. [CrossRef]

32. Castaldo, S.; Perrini, F.; Misani, N.; Tencati, A. The missing link between corporate social responsibility and consumer trust: The case of fair trade products. J. Bus. Ethics 2009, 84, 1-15. [CrossRef]

33. Swaen, V.; Chumpitaz, R. Impact of corporate social responsibility on consumer trust. Rech. Appl. Market. 2008, 23, 7-34. [CrossRef] 
34. Copeland, L. Conceptualizing political consumerism: How citizenship norms differentiate boycotting from buycotting. Political Stud. 2014, 62, 172-186. [CrossRef]

35. Buycott. Vote with Your Wallet-UPC Lookup Database, Find Barcode Scanner, Boycott, 2020. Buycott I Vote with Your Wallet. Available online: https: / / www.buycott.com/ (accessed on 24 March 2021).

36. Godfrey, M. App of the week: Buycott. ABC News Technology Review. 18 May 2013. Available online: https://web.archive.org/ web/20140321131432/http:/ / abcnews.go.com/blogs/technology/2013/05/app-of-the-week-buycott/ (accessed on 24 March 2021).

37. Caruana, R.; Chatzidakis, A. Consumer social responsibility (CnSR): Toward a multi-level, multi-agent conceptualization of the "other CSR". J. Bus. Ethics 2014, 121, 577-592. [CrossRef]

38. Du, S.; Bhattacharya, C.; Sen, S. Convergence of interests-Cultivating consumer trust through corporate social initiatives. Adv. Consum. Res. 2007, 34, 687. Available online: http://www.acrwebsite.org/volumes/12807/volumes/v34/NA-34 (accessed on 24 March 2021).

39. Baskentli, S.; Sen, S.; Du, S.; Bhattacharya, C. Consumer reactions to corporate social responsibility: The role of CSR domains. J. Bus. Res. 2019, 95, 502-513. [CrossRef]

40. De Jong, M.; Harkink, K.; Barth, S. Making green stuff? Effects of corporate greenwashing on consumers. J. Bus. Tech. Commun. 2018, 32, 77-112. [CrossRef] [PubMed]

41. Rahman, I.; Park, J.; Geng-quing, C. Consequences of "greenwashing": Consumers' reactions to hotels' green initiatives. Int. J. Contemp. Hosp. Manag. 2015, 27, 1054-1081. [CrossRef]

42. Aji, H.; Sutkino, B. The extended consequence of greenwashing: Perceived consumer skepticism. Int. J. Bus. Inf. 2015, 10, 433-468. Available online: https: / /ijbi.org/ijbi/article/view/127 (accessed on 24 March 2021).

43. Nyilasy, G.; Gangadharbatla, H.; Paladino, A. Perceived greenwashing: The interactive effects of green advertising and corporate environmental performance on consumer reactions. J. Bus. Ethics 2013, 125, 693-707. [CrossRef]

44. Christensen, L.; Morsing, M.; Thyssen, O. CSR as aspirational talk. Organization 2013, 20, 372-393. [CrossRef]

45. Wang, J.; Wu, L. The impact of emotions on the intention of sustainable consumption choices: Evidence from a big city in an emerging country. J. Clean. Prod. 2016, 126, 325-336. [CrossRef]

46. Antonetti, P.; Maklan, S. Feelings that make a difference: How guilt and pride convince consumers of the effectiveness of sustainable consumption choices. J. Bus. Ethics 2014, 124, 117-134. [CrossRef]

47. Onwezen, M.; Bartels, J.; Antonides, G. The self-regulatory function of anticipated pride and guilt in a sustainable and healthy consumption context. Eur. J. Soc. Psychol. 2014, 44, 53-68. [CrossRef]

48. Romani, S.; Grappi, S. How companies' good deeds encourage consumers to adopt pro-social behavior. Eur. J. Mark. 2014, 48, 943-963. [CrossRef]

49. Du, S.; Bhattacharya, C.; Sen, S. Reaping relational rewards from corporate social responsibility: The role of competitive positioning. Int. J. Res. Market. 2007, 24, 224-241. [CrossRef]

50. Vlachos, P.; Panagopoulos, N.; Rapp, A. Feeling good by doing good: Employee CSR-induced attributions, job satisfaction, and the role of charismatic leadership. J. Bus. Ethics 2013, 118, 577-588. [CrossRef]

51. Fornell, C.; Larcker, D.F. Structural equation models with unobservable variables and measurement error: Algebra and statistics. J. Mark. Res. 1981, 18, 39-50. [CrossRef]

52. Wright, K. Researching internet-based populations: Advantages and disadvantages of online survey research, online questionnaire authoring software packages and web survey services. J. Comput. Mediat. Commun. 2006, 10. [CrossRef]

53. Berinsky, A.; Huber, G.; Lenz, G. Evaluating online labor markets for experimental research: Amazon.com's Mechanical Turk. Political Anal. 2012, 20,351-368. [CrossRef]

54. Wang, Y.; Holznagel, K. Evolving cross-sector collaboration in the arts and culture sector: From sponsorship to partnership. Corporate Reputation Review. Advance online publication. Corp. Reput. Rev. 2020. [CrossRef] 